Ann. Génét. Sél. anim., I979, 11 (3), 24I-250.

\title{
Experience during two generations of within lines boar performance testing, using $5 \alpha$-androst-16-ene-3-one ( $5 \alpha$-androstenone) and an olfactory judgement of boar taint
}

\author{
P. JONSSON* and $\varnothing$. ANDRESEN** \\ * National Institute of Animal Science, Rolighedsvej 25, DK-I958 Copenhagen V., Denmark \\ ** Department of Reproductive Physiology and Pathology, \\ Veterinary College of Norway, PB. $8 I 46$ Oslo dep., Norway
}

\section{Summary}

The Danish work undertaken within the E.A.A.P. Commission of Pig Production working group on the production and the utilization of meat from entire male animals is presented from the Danish breeding experiment station "Tylstrup " on the basis of 845 entire male pigs of the Danish Landrace breed during the generations 1974-75 and 1976-78. From the year of herd establishment, I974-75, are given the means, the frequencies and the variation of a panel judgment of boar odour intensity (in boar fat) together with those of two steroid criteria, $5 \alpha$-androstenone (in boar fat and blood plasma) and testcsterone (in blood plasma). For the steroids, the repeatabilities (intra-blood sample) and the correlations between morning and afternoon samples are given.

The purpose of this presentation is to forward estimates of genetic parameters for the potential selection objective boar taint and of its probable genetic relation to male reproductive performance and growth. The highest estimate of p. Ioo additive gene action $\left(h^{2}\right)$ is found for a linear biological expression, adding the level of the steroid $5 \alpha$-androstenone and the olfactory panel score:

$h^{2}$ combined linear boar taint expression $=0.46 \pm 0.18 ; \mathrm{P}<0.0 \mathrm{r}$.

The heritability estimate of the important steroid in male reproduction, the testosterone, was found to be similarly high:

$h^{2}$ testosterone $=0.45 \pm 0.17 ; \mathrm{P}<0.01$.

The estimates of the phenotypic $\left(r_{\mathbf{P}}\right)$ and genetic $\left(r_{\mathrm{G}}\right)$ correlations between daily weight gain (DWG) and on the one side $5 \alpha$-androstenone and on the other side testosterone were found to be, within these two starting years of selection:

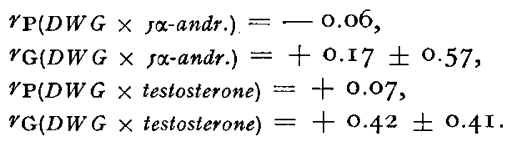

These four correlation estimates are all below the $5 \mathrm{p}$. Ioo level of significance. Significant positive correlations are found between the two steroids:

$r_{\mathbf{P}}(\varsigma \alpha$-andr. $\times$ testosterone $)=+0.43$,

$r_{\mathrm{G}}(\ulcorner\alpha$-andr. $\times$ testosterone $)=+0.88 \pm 0.18$. 
The selection procedure practised in this project, from the fall of 1978 , is performancetesting within an upward and a downward selection line on the boar taint objective, which is estimated by means of a biological index (without any economic weights), consisting of the selection probands' level of $5 \alpha$-androstenone and the olfactory panel score. The objective is to estimate as quickly as possible the realized heritability of that index and the genetic response in boar's reproductive performance and growth potential.

\section{Introduction}

In 1973, The European Association of Animal Production (E.A.A.P.) Commission of Pig Production, took the initiative to establish a working group on "Production and Utilization of Meat from Entire Male Animals " (1974). The present report is updating the relevant Danish work undertaken.

\section{Materials and Methods}

Samples were collected from 845 performance tested young boars at a live weight of $90+3 \mathrm{~kg}$. Correction for age effect was not undertaken because of the insignificance of regression in this limited live weight interval of maximum $6 \mathrm{~kg}$.

The samples of fatty tissue were collected from the live boars by use of a biopsy needle (LUNDSTRøM et al. I973) within the generations -2 (year I974-75), zero (year 1976-77) and one (year I977-78) of the selection experiment herd of Danish Landrace pigs (Table I), which was established in the winter I973-74. Samples of blood were collected from vena cava cranialis (generations -2 and zero). The level of $5 \alpha$-androstenone in fat, taken in the generations 0 and $\mathrm{r}$ (1976-78), and in peripheral plasma, taken in the generation -2 ( I974-75), were evaluated by radio-immunoassay according to ANDRESEN (I974, I975a, I977), and the peripheral plasma levels of testosterone as described by SANwAL et al. (I974). All samples were analyzed in duplicate.

The samples of fat were judged for the occurrence of boar taint by 4 women and 4 men. A ro class scale was used for the material from the generation -2 (I974-75), and a 4 class scale was then used henceforward, as suggested by the E.A.A.P. working group mentioned above for reasons of uniformity in scaling between member countries.

The foundation generation in the breeding experiment station "Tylstrup " was established by means of a stratified sampling procedure by systematically intermating boars with gilts from exactly roo litters sampled, each litter bought from one of roo elite herds which made up the elite breed nucleus of the recognition year I973-74 of the Danish Landrace pig, i.e. Ioo litters out of the total of $867 \mathrm{I}$ litters produced that year within the elite nucleus, or I.I 5 p. roo of litters sampled.

The successive generations are partitioned into seasonal blocks of 80 to roo contemporary probands for selection. Heritabilities and genetic correlations are estimated from the within-lines sire components of variance and of covariance. 







\section{Results and Discussion}

\section{I974-75: The year of herd establishment}

The results of the organoleptic judgement for boar taint in the foundation generation is given in Table 2. As the difference between gilts and young boars proved to be highly significant $(P \leqslant 0.00 r)$, the gilts were not tested for sex odour intensity in the following generations. The difference between the two sexes is demonstrated in the frequency distributions, the minimum and the maximum points, the standard deviations, and the coefficients of variation in the two sexes, all given in Table 2 .

TABLE 2

Boar odour intensity in the foundation generation $1974-75$. Olfactory panel judgement. A ro class scale was used

Intensité de l'odeur sexuelle de verrat dans la génération fondatrice $1974-75$, jugement du jury d'olfaction sur une échelle de to points

\begin{tabular}{|c|c|c|c|}
\hline & $\begin{array}{l}\text { Live weight } \\
\text { (Poids vif) }\end{array}$ & $\begin{array}{l}\text { Odour intensity, points } \\
\text { (Odeur) }\end{array}$ & $\begin{array}{l}\text { Difference } \\
\text { boars-gilts } \\
\text { (Différence } \\
\text { mâle-femelle) }\end{array}$ \\
\hline 200 gilts (200 femelles) . . . . . . & $87 . \mathrm{I} \mathrm{kg}$ & $\begin{array}{l}2.02 \pm 0.03: \\
\text { very weak and uncertain }\end{array}$ & $\begin{array}{l}\text { r.r2 points } \\
\mathrm{P} \leqslant \mathrm{O} \text {.oor }\end{array}$ \\
\hline
\end{tabular}

Frequency distribution, p. Ioo (Distribution de fréquence, p. гоo) :

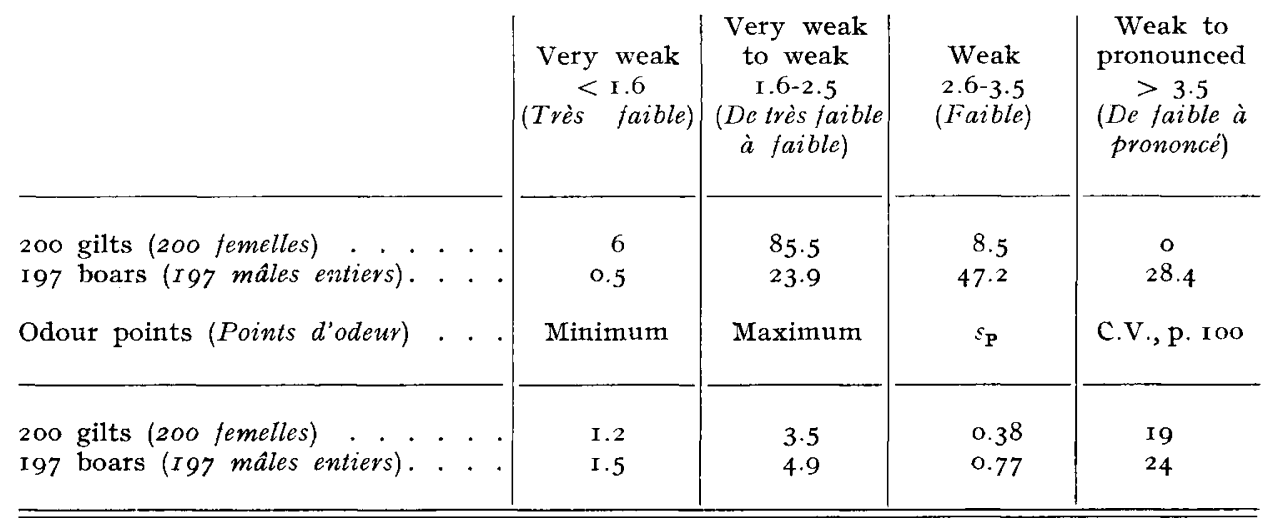

The level of $5 \alpha$-androstenone and testosterone in boar peripheral plasma in the foundation generation is given in Table 3 . From the table section $A$ it is seen that the mean level and the variation, both absolute and relative, in the $5 \alpha^{-}$ 
androstenone level are slightly lower than those three estimates for testosterone.

The sufficient accuracy in the biochemical analysis is proved by the intraclass correlation between the first and the second duplicates within the same boar within the same plasma as shown in the Table section $3, \mathrm{~B}$.

TABLE 3

Levels of $5 \alpha$-androstenone and testosterone in boar peripheral plasma and their intraclass correlations and phenotypic correlation. Foundation generation I974-75

Niveaux de la $5 \alpha$-androsténone et de la testostérone dans le plasma de verrat et leurs corrélations (intra-classe et phénotypique). Génération fondatrice 1974-75

\begin{tabular}{|c|c|c|c|}
\hline & $\mathrm{ng} / \mathrm{ml}$ & $\varepsilon_{\mathrm{P}}, \mathrm{ng} / \mathrm{ml}$ & C.V., p. I0o \\
\hline 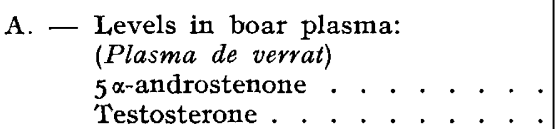 & $\begin{array}{l}5.27 \pm 0.45 \\
6.98 \pm 0.41\end{array}$ & $\begin{array}{l}3.03 \\
4.84\end{array}$ & $\begin{array}{l}5^{8} \\
69\end{array}$ \\
\hline $\begin{array}{l}\text { B.- Accuracy in biochemical analysis } \\
\text { (Précision de l'analyse biochimique) } \\
\text { Intraclass correlation within same } \\
\text { boar between analyses I and } 2 \text { of } \\
\text { same plasma . . . . . . . . . . . } \\
\text { (Corrélation intra-classe sur } 2 \text { ana- } \\
\text { lyses du même plasma) }\end{array}$ & $5 \alpha$-androstenone & & $\begin{array}{c}\text { Testosterone } \\
0.98\end{array}$ \\
\hline $\begin{array}{l}\text { C. - Biological difference in steroid } \\
\text { levels, blood taken morning and } \\
\text { afternoon: time diff. } 7 \text { hrs } \\
\text { (Prises de sang du matin et de } \\
\text { l'après-midi, distantes de } 7 \text { h) } \\
\text { Correlation morning } \times \text { afternoon } \\
\text { plasmae. . . . . . . . . . . . } . \cdot \\
\text { (Corrélation plasma du matin } \times \\
\text { plasma de l'après-midi) }\end{array}$ & $0.8 \mathrm{I}$ & & $0.6 \mathrm{I}$ \\
\hline $\begin{array}{l}\text { D. Intraclass correlation between two } \\
\text { fullbrothers within the same litter } \\
\text { (Corrélation entre frères de portée) }\end{array}$ & 0.17 & & 0.25 \\
\hline $\begin{array}{l}\text { E. - Phenotypic correlation between } \\
\text { testosterone and } 5 \alpha \text {-androstenone. } \\
\text { Mean values of diurnal variation } \\
\text { (Corrélation phénotypique entre } 5 \alpha- \\
\text { androsténone et testostérone) }\end{array}$ & & $0.7^{8}(\mathrm{P}<0.01)$ & \\
\hline
\end{tabular}

The levels of $5 \alpha$-androstenone and testosterone in peripheral plasma of boars are not constant during a 24 hours cycle (ANDRESEN I975b, CLAUS and GIMÉNEZ, I977). In order to reduce the effect of this variation, from each boar one sample of peripheral plasma was collected in the morning and another 7 hours later. In Table 3 , section $\mathrm{C}$, is seen that the correlation between the morning plasma and the afternoon plasma levels of the steroid $5 \alpha$-androstenone was $r=0.8 \mathrm{r}$, whereas that between the morning plasma and the afternoon plasma levels of the steroid 
testosterone was only $r=0.6 \mathrm{r}$. It is apparent that this morning and afternoon sampling of blood with 7 hrs distance seemed sufficient to reduce the diurnal variation of $5 \alpha$-androstenone considerably, but no that of testosterone. The difference between the two correlation coefficients, $0.8 \mathrm{I}$ vrs. $0.6 \mathrm{I}$, being transformed to their specific $z$-values, proved to be significant at the probability level of $P \leqslant 0.00 r$. The values of the two periods were then pooled, and the phenotypic correlation between those mean values of testosterone and $5^{\alpha}$-androstenone was $r_{\mathbf{p}}=+0.78$ (within boar within diurnal time). This correlation is given in the section $\mathrm{E}$ of Table 3. In the following calculations, the mean steroid level of the two samples collected $7 \mathrm{hrs}$ if apart has been used.

Of interest is the intra-litter correlation between two full-brothers in Table 3 , section D (93 degrees of freedom) of 0.17 and of 0.25 for the two steroid levels, respectively. When doubling these, a rough heritability estimate is obtained for each steroid, which may be compared with the corresponding estimates in Table 5 .

\section{I976-I978}

The mean level of the three selection criteria in question in these two years, together with the daily weight gain, were as given in Table 4 .

The phenotypic correlation between $5^{\alpha}$-androstenone and odour intensity, both in boar fat, was found to be $r_{\mathbf{p}}=:=+0.5$. This estimate was in agreement with MALMFORS and ANDRESEN (I975).

The reasoning behind the linear combination of the boar odour panel score and the level of $5 \alpha$-androstenone was to combine an expression of the consumer's response (housewife's criterion) with the steroid response of the animal itself, the level of $5 \alpha$-androstenone. Before combining these two variates, each of them was of course expressed relative to its own standard deviation, and these two variates were then added, constituting the combined expression of boar taint.

Table 5 demonstrates clearly the improvement in the estimation of genetic action against boar taint in the consumer's product when using this combined expression. It is promising that this "biological " criterion yields the highest estimation of relative gene action.

In the sequence of their selection project against and for boar taint, using only the level of $5 \alpha$-androstenone and using the selection response evaluation technique given by HILL (I972), WILLECKE et al. (I979) obtained, combining their first three generations of selection, realized heritability estimates of similar magnitude as those given in Table 5 .

In their Danish Landrace breed nucleus performance test on elite herds investigation, JONSSON and WISMER-PEDERSEN (I974) found a heritability estimate of $h^{2}=0.54 \pm 0.32$ ( 42 d.f. for sires, $0.05 \leqslant P \leqslant 0.10$ ), which is comparable to the last estimate given in Table 5 , but not with respect to its standard error of estimate.

The heritability estimate of the testosterone level was found to be in the same range as for $5 \alpha$-androstenone, and in Table 6 it is demonstrated that a significant genetic covariation exists between $5^{\alpha}$-androstenone and testosterone. At the breeding experiment station, therefore, an upward and a downward selection line were started in the autumn of 1978 to demonstrate as quickly as possible the correlated response on the level of testosterone when selecting solely on the combination of the two boar taint criteria, as discussed above. 


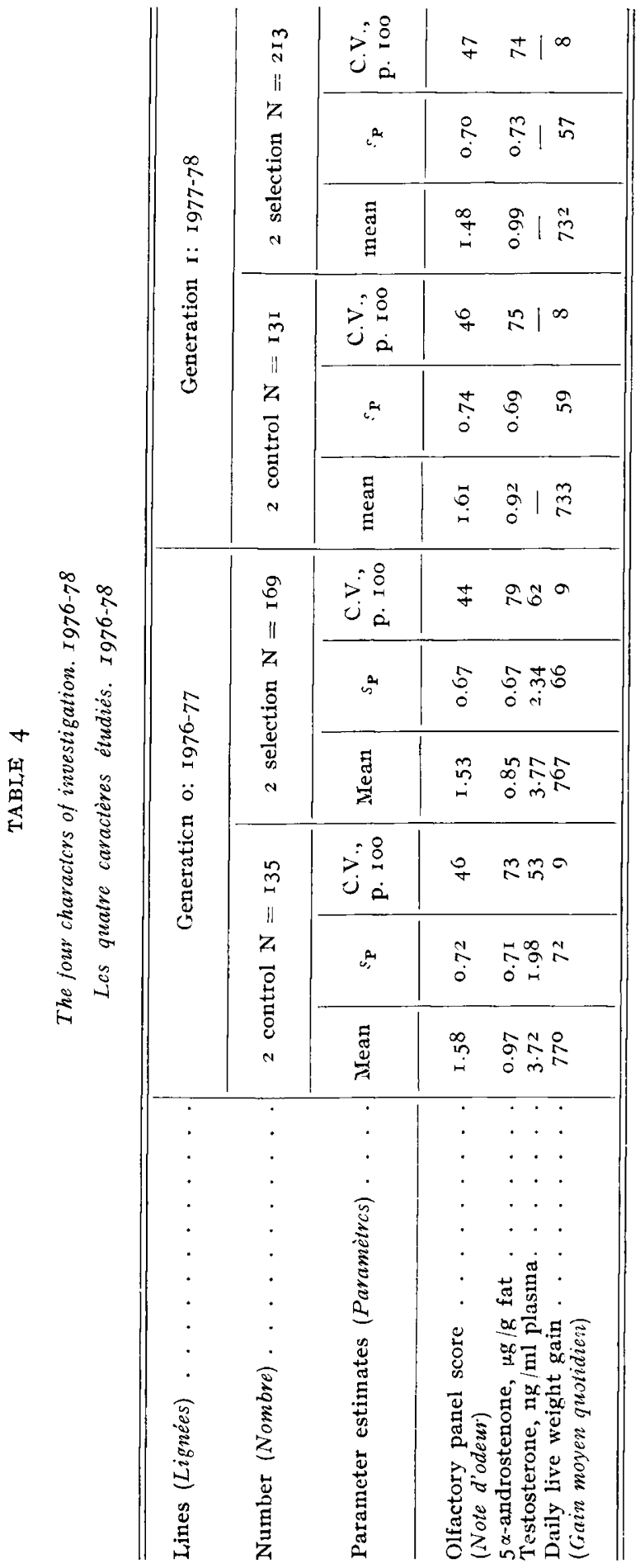


TABLE 5

Heritability estimates of the levels of the steroids $5 \alpha$-androstenone in boar fat and testosterone in blood plasma at go $\mathrm{kg}$ live weight, the olfactory panel score at go $\mathrm{kg}$, the combination of the olfactory panel scove with the $5 \alpha$-androstenone level, and the daily weight gain from $25 \mathrm{~kg}$ to $90 \mathrm{~kg}$ live weight. Danish Landrace. Estimates are within breeding lines.

Héritabilités des niveaux de la $5 \alpha$-androsténone dans le tissu gras de vervat et de la testostérone dans le plasma sanguin au poids vif de $90 \mathrm{~kg}$, de la note d'olfaction à $90 \mathrm{~kg}$, de la combinaison de la note d'olfaction avec le niveau de $5 \alpha$-androsténone et du gain de poids journalier de 25 à $90 \mathrm{~kg}$ de poids vif. Landrace danois. Les estimées sont calculées intra-lignée.

I976-77 : 304 young boars tested (304 verrats testés)

1977-78 : 344 young boars tested (374 vcrrats testés)

Daily gain from 25 to $90 \mathrm{~kg}$ live weight

(Gain de poids journalier)

Level of testosterone

(Niveau de testostérone)

Level of $5 \alpha$-androstenone . . . . . . . . . . $1976-78$

(Niveau de $5 \alpha$-androsténone)

Olfactory panel score . . . . . . . . . . ${ }_{1976-78}$

(Note d'odeur)

Level of $5 \alpha$-androstenone, lineatly combined with olfactory panel score . . . . . . . . . . . . .

(Niveau de $5 \alpha$-androsténone combiné linéairement avec la note d'odeur)
Years

included

(Années)

Heritability

estimate

(Héritabilité)

$197^{6-78}$

$0.3^{8} \pm 0.12$

$0.45 \pm 0.17$

$0.25 \pm 0.13$

$0.33 \pm 0.15$

1976-78

\section{TABLE 6}

Estimates of covariation between levels of $5 \alpha$-androstenone and testosterone and between each of those and daily gain. Years of test 1976-78:648 young boars tested at $90 \mathrm{~kg}$ live weight gain. Estimates are within breeding lines.

Estimées de la covariance entre les niveaux de $5 \alpha$-androsténone et de testostérone entre ces niveaux et le gain journalier. Années $1976-78: 6.48$ jeunes verrats contrólés à go $\mathrm{kg}$ de poids vif. Les estimées sont calculées intra-lignée.

\begin{tabular}{|c|c|c|}
\hline $\begin{array}{l}\text { Correlation } \\
\text { (Corrélation) }\end{array}$ & $\begin{array}{c}\text { Phenotypic } \\
\text { (Phénotypique) }\end{array}$ & $\begin{array}{l}\text { Additive genetic } \\
\text { (Génétique) }\end{array}$ \\
\hline $\begin{array}{l}\text { Level of } 5 \alpha \text {-androstenone in boar fat } \times \text { level of test- } \\
\text { osterone in blood plasma. Generation } 0 \text {, } 1976-77 \cdot . \\
\text { (Niveau de } 5 \alpha \text {-androsténone dans le tissu gras } \times \text { niveau } \\
\text { de testostérone dans le plasma) }\end{array}$ & $\begin{array}{c}+0.43 \\
\mathrm{P} \leqslant 0 . \mathrm{OI}\end{array}$ & $\begin{array}{c}+0.88 \pm 0.18 \\
P \leqslant 0.001\end{array}$ \\
\hline $\begin{array}{l}\text { Level of } 5 \alpha \text {-androstenone in boar fat } \times \text { daily weight } \\
\text { gain. Generation o and } 1 \text {, } 1976-78 . \cdot \cdot \cdot \cdot \cdot \cdot \cdot \\
\text { (Niveau de } 5 \alpha \text {-androsténone dans le tissu gras } \times \text { gain } \\
\text { moyen quotidien) }\end{array}$ & not signif. & $\begin{array}{l}+0.17 \pm 0.57 \\
\text { not signif. }\end{array}$ \\
\hline 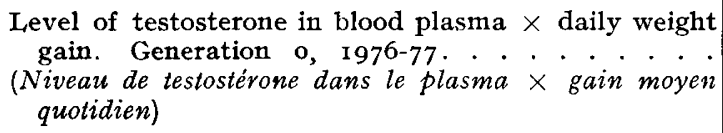 & $\begin{array}{c}+0.071 \\
\text { not signif. }\end{array}$ & $\begin{array}{l}+0.42 \pm 0.4 \mathrm{I} \\
\text { not signif. }\end{array}$ \\
\hline
\end{tabular}


The response to libido, reproduction and weight gain will also be followed very carefully. A control line is maintained alongside, contemporarily. Therefore, the testosterone level is determined in the plasma of each boar pig reaching $90 \mathrm{~kg}$ live weight in that experimental herd.

The relationship between each of the two steroid levels to daily weight gain is only negligible and not significant (see Table 6). These relationships have, however, to be carefully followed along with libido and other reproduction criteria in order to study the selection response upon these criteria.

From 1978 , the determination of $5 \alpha$-androstenone in boar fat has been performed by a simplified method, giving relative concentrations of the steroid in counts per minute (C.P.M.) (ANDRESEN, I979). The selection procedure practised from the same year is mass selection on the basis of performance test within and across selection blocks of contemporary animals of similar age.

Rę̧u pour publication en décembre 1979.

\title{
Résumé
}

\author{
Expérience sur deux générations d'un contrôle individuel de verrats

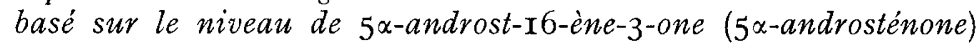 \\ et un jugement olfactif des défauts d'odeur sexuelle dans le tissu gras
}

\begin{abstract}
Des recherches ont été entreprises au Danemark à la suite des recommandations d'un groupe de travail de la Commission Porcine de la Fédération Européenne de Zootechnie sur la production et l'utilisation de viande en provenance de mâles entiers. Cet article est basé sur l'étude de 845 porcs mâles entiers, de la race Landvace danois, à la station expérimentale de "Tylstrup ", couvrant les générations I974-75 et 1976-78. Depuis la fondation de ce troupeau, en 1974-75, 1'intensité de l'odeur sexuelle de verrat est jugée par un jury d'olfaction et deux stéroïdes sont analysés, la $5^{\alpha}$-androsténone (dans le tissu gras du verrat et le plasma sanguin) et la testostérone (dans le plasma sanguin). Les distributions de ces mesures sont étudiées et, pour les stéroïdes, les répétabilités sont données intra-échantillon de sang $(0,97$ et 0,98 respectivement pour la $5 \alpha-$ androsténone et la testostérone) et les corrélations calculées entre l'échantillon du matin et celui de l'après-midi (o,8I et $o, 6$ I respectivement pour les mêmes stéroïdes).

Dans la perspective d'une sélection pour éliminer les défauts d'odeur sexuelle, les paramètres génétiques des mesures précédentes sont estimés ainsi que leurs relations génétiques éventuelles avec les performances de reproduction du mâle et avec la croissance. L'estimation la plus élevée du pourcentage de variance génétique additive $\left(h^{2}\right)$ est trouvée pour une combinaison linéaire de la $5 \alpha$-androsténone et de la note du jury d'olfaction, obtenue en additionnant ces deux variables exprimées chacune en unité d'écart-type:
\end{abstract}

$h^{2}$ expression linéaire combinée du défaut d'odeur $=0,46 \pm 0, \mathrm{I} 8 ; \mathrm{P}<\mathrm{o}, \mathrm{or}$.

Une héritabilité élevée est également trouvée pour le taux de testostérone, stéroïde important dans la reproduction mâle :

$h^{2}$ testostérone $=0,45 \pm 0, \mathrm{r} 7 ; \mathrm{P}<0,0 \mathrm{r}$.

Les estimées des corrélations phénotypiques $\left(\gamma_{\mathrm{P}}\right)$ et génétiques $\left(\gamma_{\mathrm{G}}\right)$ entre le gain moyen quotidien (GMQ) et d'une part la $5 \alpha$-androsténone et d'autre part la testostérone sont les suivantes :

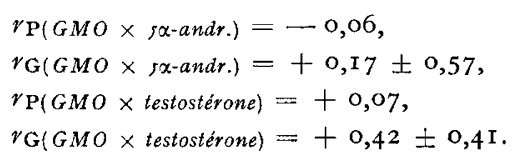


Ces quatre corrélations sont toutes au-dessous du seuil de signification à 5 p. Ioo. Par contre, les corrélations entre les deux stéroïdes sont significatives :

$\gamma_{\mathrm{P}}($ sg-andr. $\times$ testostérone $)=+0,43$,

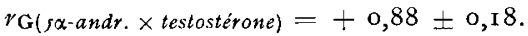

Depuis l'automne I978, une lignée sélectionnée vers le haut et une lignée sélectionnée vers le bas sont constituées, l'objectif étant d'accroître ou de réduire les défauts d'odeur sexuelle de verrat dans ces deux lignées en utilisant l'indice défini plus haut qui combine le niveau de $5^{-\alpha}$ audrosténone et le test olfactif. Cette expérience vise à estimer aussi rapidement que possible l'héritabilité réalisée de cet indice et les réponses indirectes sur la reproduction du verrat et sur le potentiel de croissance.

\section{Acknowledgement}

The authors want to express their gratitude to the Agricultural Research Conncil of Norway for the financial support given to this investigation.

\section{References}

ANDRESEN $\varnothing$., 1974. Development of a radioimmunoassay for $5 \alpha$-androst-16-en-3-one in pig peripheral plasma. Acta Endocr., 76, 377-387.

ANDRESEN $\varnothing$., I975a. A radioimmunoassay for $5 \alpha$-androst-16-en-3-one in porcine adipose tissue. Acta endocr., 79, 619-624.

ANDRESEN $\varnothing$., $1975^{b} .5 \alpha$-androstenone in peripheral plasma of pigs, diurnal variation in boars, effects of intravenous $\mathrm{HCG}$ administration and castration. Acla Endocr., 78, 385-39r.

ANDRESEN $\varnothing$., I977. Radioimmunological estimation of $5 \alpha$-androstenone and studies on its occurrence in boar pheripheral plasma and fat, with some reference to plasma testosterone levels. Oslo, I977.

ANDRESEN $\varnothing$., r979. A rapid radioimmunological evaluation of the androstenone content in boar fat. Acta vet. scand., 20,343-350.

Claus R. and Gimenez T., I977. Diurnal rhythm of $5 \alpha$-androst-16-en-3-one and testosterone in peripheral plasma of boars. Acta Endocr., 84, 200-206.

EAAP Working Group on "Production and Utilization of Meat from Fntire Male Animals", 1974. The European Association for Animal Production, Rome.

HIr. W. G., I972. Estimation of realized heritabilities from selection experiments. I. Divergent selection. Biometrics, 28, 747-765.

Jonsson P. and WISMER-PEDERSEN J., I974. Genetics of sex odour in boars. Livestock Production Science, 1, 53-66.

Lundstrøm K., Asp-Malmfors B. and Hansson I., 1973. A simple biopsy technique for obtaining fat and muscle samples from pigs. Swedish. J. Agric. Res., 3, 2 I I-2 I 3.

MALMFORS B. and ANDRESEN $\varnothing$., I975. Relationship between boar taint intensity and concentration of $5 \alpha$-androst-16-en-3-one in boar peripheral plasma and backfat. Acia Agric. Scand., 25, $92-96$.

Sanwal, P. C., Sundby A., Edduist L. E., I974. Diurnal variation of peripheral plasma levels of testosterone in bulls measured by a rapid radioimmunosssay procedure. Acta vet. scand., 15, 90-99.

Willecke H., Claus R., Pirchner F. and Alsing W., 1979. Selektions-experiment auf Ebergeruch. Arbeitstagung des Ausschusses der DGfz für genetisch-statistische Methoden in der Tierzucht. Jever, I5-I7 März 1979. 